\title{
Quality Education Factor Effects on Student Satisfaction in Saudi Arabian Universities
}

\author{
May Alashwal \\ Department of Learning Sciences and Educational Research, University of Central Florida, Orlando, FL 32816, \\ USA
}

\begin{abstract}
This research examines the level of student satisfaction in Saudi Arabian universities. The research studied factors such as classroom facilities, available courses, learning environment, e-learning methods, type of leadership, and instructor's expertise. Four-hundred students responded to a questionnaire on three different campuses with a 5point Likert scale. Regression analysis results of student responses showed a significant impact on students' satisfaction with varying degrees of strength. Most importantly, classroom facilities and instructor expertise had a more substantial effect among all variables, whereas learning environment and type of leadership had the least impact. Hence, university policymakers should focus more on classroom facilities and instructor expertise to increase students' satisfaction in their universities.
\end{abstract}

Keywords: Classroom facilities, Available courses, Learning environment, E-learning methods, Type of leadership, Instructor's expertise, Education Quality

DOI: $10.7176 / \mathrm{JEP} / 11-9-10$

Publication date:March $31^{\text {st }} 2020$

\section{Introduction}

Saudi universities play a significant role in the socioeconomic development of the country. The higher education sector has been rapidly increasing around the world, with the digital rise and industrial mass production requiring educators and university leaders to improve or develop new learning methods and classroom environments in higher education. Improved learning methods and classroom environments have been found to lead to increased higher education costs (Allam, 2020). Competition has also increased to a significant degree with the rise of universities in Saudi Arabia; the number of universities in Saudi Arabia jumped from 7 in 2005 to 30 in 2016 (Alghamdi \& Hamed Alanazi, 2019). Technical and diplomat institutions have also increased. Today, university students can instantly obtain information due to advanced digital communications and technologies. In this rapidly changing and competitive education environment, universities that provide quick and reliable changes in their learning methods and classroom environment can excel and prosper. These changes are vital factors influencing their future alumni and students' careers.

Many studies have analyzed the factors that have the most effect on student satisfaction and improved quality education. Appropriate learning methods and suitable classroom environments have a substantial impact on education quality (Aldridge \& Rowley, 1998; Bell \& Brooks, 2019; Mastoi \& Saengkrod, 2019; Skrbinjek \& Dermol, 2019). One analysis indicated that university improvements of their learning methods and classroom environment need to satisfy their students' demands and expectations. Moreover, any changes and enhancements affect student academic achievements and faculty performance (Chandramohan, 2019). In Saudi Arabia, in the last decade, we have carried out many changes in the undergraduate education sector. The government has provided financial and logistic support for both students and faculty in public and private undergraduate education universities. The Ministry of Education has encouraged universities to open more colleges and departments in different fields to satisfy market needs and trends. It has also equipped laboratories and classrooms with high-tech instruments to improve classroom environment quality (Albejaidi \& Nair, 2019). The substantial reforms by the Ministry of Education in university-level education have led to tremendous growth and competition among local universities. However, the improvements and strategies in the universities need to be monitored by the Ministry of Education to validate whether or not they satisfy the market needs in both the short and long term and ensure that different universities vary in their programs and learning methods to ensure a wide range of variation among universities.

Many studies have investigated how students are satisfied with their university education quality (Ali, Zhou, Hussain, Nair, \& Ragavan, 2016; Muhsin, Nurkhin, Pramusinto, Afsari, \& Arham, 2020; Weili \& Dilong, 2020). A variety of factors were found to affect student satisfaction with respect to their university's education services. Previously, students' direct contact with faculty members was found to be related to college withdrawal (Fematt et al., 2019). The level of retention of students was also a sign of student satisfaction with the education quality of their universities (Terzic, Kozina, \& Ascic-Kubat, 2019). In 1997, a faculty mentoring program was introduced to relate academic performance with student retention rates (Campbell \& Campbell, 1997; Deepika, 2020). Another study evaluated students' satisfaction level in UK universities (Imran, Omar, Allah, \& El All, 2019); a poor education quality model was found to be the main factor for measuring satisfaction level. That study revealed that 
educational organizations should relate dissatisfaction levels to the rates of retention. A recent analysis assessed the psychological factors for university persistence, such as social competence and support, self-esteem, and personal conscientiousness (Carales, 2020; Napoli \& Wortman, 1998). Another study provided a model that relates education quality to student loyalty and concluded that teaching quality and students' emotions are vital for building student loyalty (Wu \& Cheng, 2020).

\section{Methodology}

\subsection{Theoretical Framework}

Based on the above literature review, the current study allocated educational service factors to measure their influence on student satisfaction. These factors included classroom facilities, available courses, learning environment, e-learning methods, type of leadership, and instructor's expertise. These are the factors to measure student satisfaction that are included in the questionnaire on the three university campuses and are designed to answer the following research questions:

Research Question 1: Which educational service factor has the most effect on student satisfaction in Saudi Arabian universities?

Research Question 2: What are the different effects and significance of educational service factors on student satisfaction in Saudi Arabian universities?

\subsection{Research Design}

The research design in this study is based on the reviewed literature that suggests a link between the educational service factors and student satisfaction level. Based on that, the research design is in Figure 1.

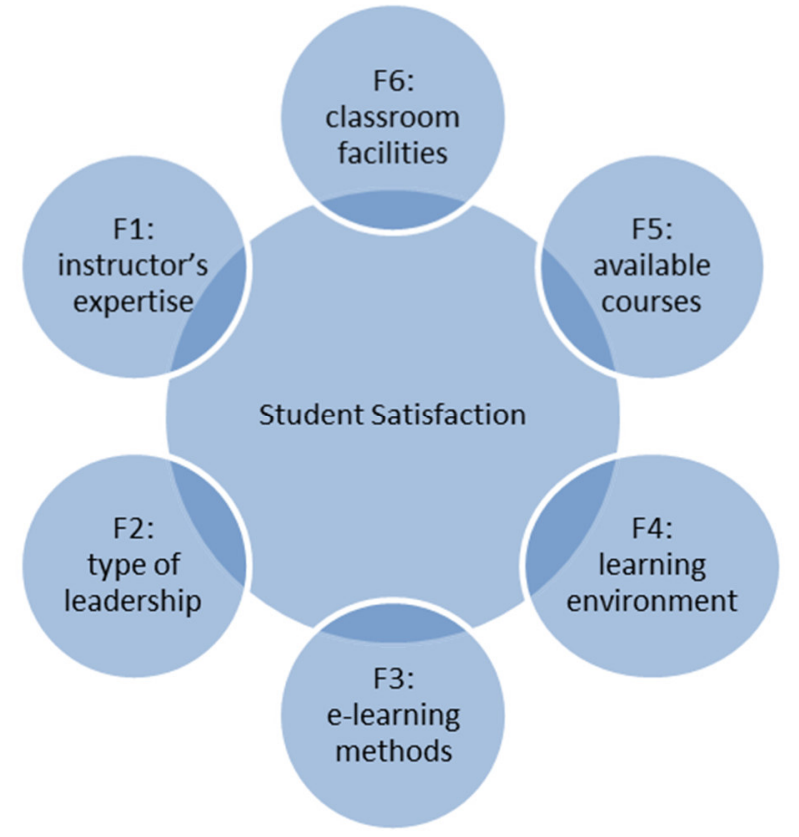

Figure 1: Educational service factors affecting student satisfaction.

\subsection{Study Procedure}

This research studied educational service factors that influence student satisfaction: classroom facilities, available courses, learning environment, e-learning methods, type of leadership, and instructor's expertise. The questionnaire had explicit instruction for the respondents to help them complete the answers correctly. The questionnaire was distributed among 500 students on three different Saudi campuses of two universities using a 5point Likert scale. The students were divided into two categories: male and female. The questionnaire was based on the instruments used by (Aldemir \& Gülcan, 2004; DeShields, Kara, \& Kaynak, 2005; Mai, 2005) in their research. SPSS was used to perform analyses, regressions, and independent sample t-tests.

The questionnaire comprised 8 sections:

1- Section 1: demographical attributes such as age, gender, college, credit hours completed, and discipline.

2- $\quad$ Section 2: shows questions that measure the current level of student satisfaction based on 5 points (1) very satisfied, (2) satisfied, (3) neutral, (4) dissatisfied, (5) strongly dissatisfied.

3- Section 3-8: measures the educational service factors: classroom facilities, available courses, learning environment, e-learning methods, type of leadership, and instructor's expertise. The range of the 
5-point Likert scale was (1) strongly agree, (2) agree, (3) neutral, (4) disagree, (5) strongly disagree.

\subsection{Participant profiles}

There were 400 participants from 3 different campuses of two Saudi Arabian universities. The questionnaire was distributed to 550 students; 430 students responded with incomplete answers and 400 responded with complete answers. Table 1 shows the profile of the participants and their frequency.

Table 1: Participant profiles in the study.

\begin{tabular}{lccc}
\hline Study profile (400 students) & Campus 1 & Campus 2 & Campus 3 \\
\hline Male participants & 98 & 125 & 53 \\
Female participants & 56 & 47 & 21 \\
Credit hours completed (avg.) & $67 \mathrm{cr}$. & $49 \mathrm{cr}$. & $75 \mathrm{cr}$. \\
Age in years (avg.) & 21 & 20 & 22 \\
\hline
\end{tabular}

\section{Results and Discussion}

Table 2 provides the results of the questionnaire that relates the educational service factors to the university students' satisfaction. It summarizes the male and female levels of satisfaction with the statistical data.

Table 2: Student satisfaction levels by gender and statistical data.

\begin{tabular}{lcccc}
\hline Study perception (400 students) & Group & Mean & Std Dev & P-value \\
\hline \multirow{2}{*}{ Level of Satisfaction } & Male & 1.6399 & .19251 & .0000 \\
& Female & 1.9392 & .20031 & .0000 \\
\hline
\end{tabular}

The t-test is used based on the assumption of the equality of variance $(p>.05)$ to state the difference by gender of participants' satisfaction levels. The statistical data results in Table 2 summarize the participant's questionnaire answers in Table 1. The mean value of responders for male was 1.6399 and for females was 1.9392. Thus, the female level of satisfaction was less than that observed for males. This result may be due to the separation in buildings and classrooms between male and female sections. Another question arising in this context is whether females were less satisfied with the educational service factors analysed in this study. These questions will be answered explicitly later in this section. There were also fewer female participants than males, an issue that may also have affected the questionnaire results.

Table 3: Statistical data related to educational service factors based on respondents' answers.

\begin{tabular}{|c|c|c|c|c|}
\hline Dependent variable & & tudents & tion & \\
\hline Constant & .702 & $(.185)$ & [2.193] & .004 \\
\hline Classroom facilities & .402 & $(.094)$ & [4.152] & .002 \\
\hline Learning environment & .223 & $(.069)$ & [3.442] & .012 \\
\hline E-learning methods & .291 & $(.072)$ & {$[5.396]$} & .022 \\
\hline Type of leadership & .114 & $(.055)$ & {$[3.420]$} & .000 \\
\hline Instructor's expertise & .312 & $(.183)$ & {$[2.454]$} & .024 \\
\hline Available courses & .304 & $(.106)$ & [4.396] & .017 \\
\hline R-square & .392 & & & \\
\hline F-statistic & 48.00 & & & \\
\hline
\end{tabular}

Table 3 provides statistical data and the regression analysis related to the educational service factors based on respondents' answers. The F-statistics and R2 values demonstrate a substantial positive relationship between the dependent variables and predictors, and because the p-value was less than 0.05 , the data fitted the model well. The independent variables were $61 \%$ of the dependent variables. The regression coefficient for classroom facilities was .402 , demonstrating that this factor was highly related to student satisfaction levels. The regression coefficient for the learning environment was .223; hence, this factor was also substantially associated with student satisfaction, as was E-learning methods (.291). Leadership type was the factor least related to student satisfaction (.114), whereas instructor expertise and available courses were both highly related to such satisfaction (.312 and .304, respectively). These results supported the presented hypothesis.

\section{Conclusion and Recommendations}

Saudi universities play a significant role in the socioeconomic development in the country. The higher education sector has been rapidly increasing globally, with increased digital and industrial mass production requiring educators and university leaders to improve or invent new learning methods and classroom environments in higher education. This research analyzed various educational service factors that affect the level of student satisfaction in Saudi Arabian universities. The results, in general, showed that most students are satisfied with their universities, with a higher degree of satisfaction in males than females. All factors were found to have a strong relation with student satisfaction, to varying degrees of significance. The order of factors in terms of their significance from 
high to low was classroom facilities, instructor's expertise, available courses, E-learning methods, learning environment, and type of leadership.

Based on these results, it is recommended that university policymakers focus more on classroom facilities, instructor's expertise, and available courses to increase students' satisfaction at these universities. Upgrading classroom facilities is likely to enhance student satisfaction levels. Specialized training for instructors in teaching methods and class management is also recommended. Further, providing more courses related to the major and with a better curriculum will increase these satisfaction levels.

\section{References}

ALBEJAIDI, F. \& NAIR, K. S. 2019. Building the health workforce: Saudi Arabia's challenges in achieving Vision 2030. The International journal of health planning and management, 34, e1405-e1416.

ALDEMIR, C. \& GÜLCAN, Y. 2004. Student satisfaction in higher education. Higher education management and policy, 16, 109-122.

ALDRIDGE, S. \& ROWLEY, J. 1998. Measuring customer satisfaction in higher education. Quality assurance in education.

ALGHAMDI, A. K. H. \& HAMED ALANAZI, F. 2019. Creating scientific dialogue through social media: exploration of Saudi pre-service science teachers. Research in Science \& Technological Education, 37, 471491.

ALI, F., ZHOU, Y., HUSSAIN, K., NAIR, P. K. \& RAGAVAN, N. A. 2016. Does higher education service quality effect student satisfaction, image and loyalty? Quality assurance in education.

ALLAM, Z. 2020. Demystifying the Aspect of Quality in Higher Education: Insights From Saudi Arabia. SAGE Open, 10, 2158244019899057.

BELL, A. R. \& BROOKS, C. 2019. Is there a 'magic link'between research activity, professional teaching qualifications and student satisfaction? Higher Education Policy, 32, 227-248.

CAMPBELL, T. A. \& CAMPBELL, D. E. 1997. Faculty/student mentor program: Effects on academic performance and retention. Research in higher education, 38, 727-742.

CARALES, V. D. 2020. Examining Educational Attainment Outcomes: A Focus on Latina/o Community College Students. Community College Review, 48, 195-219.

CHANDRAMOHAN, S. 2019. Student Satisfaction through Service Quality A Review on Higher Education Sector. Archives of Business Research, 7, 242-249.

DEEPIKA, M. 2020. Innovative Mentoring Practices at Workplace. Studies in Indian Place Names, 40, 348-351.

DESHIELDS, O. W., KARA, A. \& KAYNAK, E. 2005. Determinants of business student satisfaction and retention in higher education: applying Herzberg's two-factor theory. International journal of educational management.

FEMATT, V. L., GRIMM, R. P., NYLUND-GIBSON, K., GERBER, M. M., BRENNER, M. B. \& SOLÓRZANO, D. 2019. Identifying transfer student subgroups by academic and social adjustment: A latent class analysis. Community College Journal of Research and Practice, 1-17.

IMRAN, M., OMAR, T. K., ALLAH, A. A. F. \& EL ALL, W. A. A. 2019. The Impact of Higher Education Quality on Student's Satisfaction: Empirical Evidence from PR China. Pacific International Journal, 2, 2635.

MAI, L.-W. 2005. A comparative study between UK and US: The student satisfaction in higher education and its influential factors. Journal of Marketing Management, 21, 859-878.

MASTOI, A. G. \& SAENGKROD, L. X. W. 2019. Higher Education Service Quality based on Students' Satisfaction in People's Republic of China. Higher Education, 10.

MUHSIN, S., NURKHIN, A., PRAMUSINTO, H., AFSARI, N. \& ARHAM, A. F. 2020. The Relationship of Good University Governance and Student Satisfaction. International Journal of Higher Education, 9.

NAPOLI, A. R. \& WORTMAN, P. M. 1998. Psychosocial factors related to retention and early departure of twoyear community college students. Research in Higher Education, 39, 419-455.

SKRBINJEK, V.\& DERMOL, V. 2019. Predicting students' satisfaction using a decision tree. Tertiary Education and Management, 25, 101-113.

TERZIC, E., KOZINA, G. \& ASCIC-KUBAT, A. 2019. LINKING STUDENTS'SATISFACTION WITH COMMUNICATION WITH PROFESSORS WITH STUDENTS'SATISFACTION WITH FACULTY AND RE-ENROLLMENT ATTITUDE OF THE SAME STUDY. Economic and Social Development: Book of Proceedings, 417-426.

WEILI, H. \& DILONG, C. 2020. Investigation and Analysis on the Satisfaction of Master's Education Quality in Chongqing. Higher Education Research, 5, 17.

WU, H.-C. \& CHENG, C.-C. 2020. Relationships between experiential risk, experiential benefits, experiential evaluation, experiential co-creation, experiential relationship quality, and future experiential intentions to travel with pets. Journal of Vacation Marketing, 26, 108-129. 